\title{
Regulation of herbal medicine in Hungary
}

\begin{abstract}
In order to meet the growing needs of the European Union medicinal and aromatic plants, Hungary is still one of the major exporters today, although earlier, until the $1980 \mathrm{~s}$, we were considered a great herb-growing nation. Therefore, the development of the national medicinal and aromatic herb growing sector is an essential requirement for maintaining and developing our market position. The natural conditions of Hungary favor the cultivation of medicinal and aromatic plants. There are more than 330 herbs in our country. About seventy percent of the drugs grown and harvested are exported. However, significant changes are needed in domestic sales and further processing in order to become a leading industrial sector. Hungary also possesses modern separation techniques and large instruments for analysis, which allow the proper analytical examination of drugs and the precise determination of their active substances. Our universities and research institutes are also prepared to study the active ingredients of herbs by molecular biological methods, which may allow the exact mechanism of action of bioactive substances to be determined and the herbs to be reassessed. Our accession to the European Union the palette of products made from former herbs has significantly changed. From 2013, the category of medicinal product was discontinued and the preparations were classified as either food or medicine. However, there are significant costs associated with qualifying as a drug, so drugs or extracts are largely added to dietary supplements. As a result, the strange situation is that dietary supplements are prohibited from making any health claims, even though the dietary supplement is actually not for the benefit of a healthy population, but for those who have a health problem or do not have suitable foods, which are rich in bioactive substances.
\end{abstract}

The justification of phytotherapy must be demonstrated, depending on the state of the art. In the context of safe therapy, studies must follow the requirements of medicines and only then can they become herbal medicines. There is still much to be desired in this area in our country. Classification as a drug is based on expensive animal tests and clinical studies. A new problem arises here, as herbal cure is currently part of the arsenal of complementary medicine. With few exceptions, clinical doctors do not use herbal therapies. Patients usually ask the advice of pharmacists, naturalists, and more rarely, dietitians.

At the Arteriosclerosis Research Group, at the II. Department of Medicine and Institute of Pharmacognosy several decades of biomedical research have served and serve the purpose of evaluating and reassessing the effects of plants used in folk medicine. Over the years, we have been searching for drugs, extracts, and medicines of natural origin that are useful in liver and intestinal diseases known in folk medicine, and are believed to have lipid lowering, antioxidant and immune stimulating effects. In the article, animal and human studies will be also presented.

Keywords: medical plants, current methods, human studies
Volume I3 Issue I - 2020

\author{
Gabriella Hegyi,' Anna Blázovics² \\ 'Pecs TCM Confucius Institute, Pecs University, Hungary \\ ${ }^{2}$ Semmelweis University, Budapest, Hungary
}

Correspondence: Gabriella Hegyi, Pecs TCM Confucius Institute, Pecs University, Hungary, Email drhegy@hu.inter.net

Received: January 22, 2020 | Published: February 17, 2020
Abbreviations: EGF, epidermal growth factor; ESR, electron spin resonance spectroscopy; GC, gas chromatography; GC/MS, gas chromatography-mass spectrometry; HPLC, high-performance liquid chromatography; HPLC-DAD-MS/MS, high-performance liquid chromatography with diode-array detection tandem mass spectroscopy; ICP-OES, inductively coupled plasma optical emission spectroscopy; OPTLC, over pressured thin-layer chromatography; PSA, prostate specific antigen

\section{Drug growing and research in brief}

In order to meet the growing needs of the European Union medicinal and aromatic plants, Hungary is still one of the major exporters today, although earlier, until the 1980 s, we were considered a great herb-growing nation. Therefore, the development of the national medicinal and aromatic herb growing sector is an essential requirement for maintaining and developing our market position.
The natural conditions of Hungary favor the cultivation of medicinal and aromatic plants. There are more than 330 herbs in our country. Of the cultivated herbs, chamomile, mint and lavender are of paramount importance.

The largest areas are mustard, poppy, fennel and coriander, as well as St. John's wort and lemongrass. Many herbs are grown farming on large-scale methods, such as cumin, anise or mustard. Marjoram or marigold can be grown in smaller areas with greater manual labor.

About seventy percent of the drugs grown and harvested are exported. The major buyers are Spain and Germany. However, significant changes are needed in domestic sales and further processing in order to become a leading industrial sector. Hungary also possesses modern separation techniques and large instruments for analysis, which allow the proper analytical examination of drugs and the precise determination of their active substances. Our universities 
and research institutes are also prepared to study the active ingredients of herbs by molecular biological methods, which may allow the exact mechanism of action of bioactive substances to be determined and the herbs to be reassessed.

\section{The problem of becoming herbal medicine}

Our accession to the European Union the palette of products made from former herbs has significantly changed. From 2013, the category of medicinal product was discontinued and the preparations were classified as either food or medicine.

However, there are significant costs associated with qualifying as a drug, so drugs or extracts are largely added to dietary supplements. As a result, the strange situation is that dietary supplements are prohibited from making any health claims, even though the dietary supplement is actually not for the benefit of a healthy population, but for those who have a health problem or do not have suitable foods, which are rich in bioactive substances. The justification of phytotherapy must be demonstrated, depending on the state of the art. In the context of safe therapy, studies must follow the requirements of medicines and only then can they become herbal medicines. There is still much to be desired in this area in our country.

Classification as a drug is based on expensive animal tests and clinical studies. A new problem arises here, as herbal cure is currently part of the arsenal of complementary medicine. With few exceptions, clinical doctors do not use herbal therapies. Patients usually ask the advice of pharmacists, naturalists, and more rarely, dietitians. Unfortunately, the worst case scenario is the most common when they are self-medicated on the basis of uncertain sources. In this case either they do not go to the doctor or they stop speaking about the herbal medicine.

It is very difficult to find right way for patients, even the doctors and pharmacists. Today in Hungary, at the beginning of August 2019, there are 17,313 dietary supplements with a notification number, and 497 dietary supplements have been listed as prohibited products by the National Institute for Food and Nutrition Science (OÉTI), one of the General Directorates of National Institute of Pharmacy and Nutrition (OGYÉI). OÉTI performs professional-methodological, scientific, research, training, professional supervision and expert tasks in the field of nutrition and food. In addition to its statutory tasks, the Institute also performs the task of notification and expertise of food supplements and foods for particular nutritional uses. The Institute's main goal is to achieve healthy nutrition and related prevention in the widest possible range of the Hungarian population.

\section{Medical biochemical research at Hungary (Semmelweis University)}

At the Arteriosclerosis Research Group, at the II. Department of Medicine and Institute of Pharmacognosy several decades of biomedical research have served and serve the purpose of evaluating and reassessing the effects of plants used in folk medicine. Over the years, we have been searching for drugs, extracts, and medicines of natural origin that are useful in liver and intestinal diseases known in folk medicine, and are believed to have lipid lowering, antioxidant and immune stimulating effects. These agents often have choleretic, cholekinetic, and intestinal motility enhancing effects.

We are adapting and developing state-of-the-art, accurate assays for in vitro and in vivo herbal extracts, herbal medicines and dietary supplements. Over the years, we have used spectrophotometric, luminometric, HPLC, GC, GC/MS, HPLC-DAD-MS/MS, OPTLC, ESR, impulse radiolysis and ICP-OES techniques to answer our questions. ${ }^{1-13}$

Direct and indirect methods were used to determine the antioxidant and scavenger properties of bioactive molecules. Spectrophotometric and luminometric methods were developed to investigate the antioxidant property in vitro and in vivo. The results obtained with these methods were compared with ESR, pulse radiolysis and amperometric techniques. ${ }^{2,14}$ Luminometric methods suitable for routine examinations have also been developed in humans. ${ }^{15-18}$ In our animal experiments, biochemical, immunological and quantitative analytical studies were supplemented with morphological studies. ${ }^{19-23}$

Light and electron microscopy images confirmed tissue damage caused by free radicals and the beneficial physiological effects of natural antioxidants. Preparations were investigated in short term animal experiments (alimentary hyperlipidemia, partial hepatectomy, cannulation of the ductus choledochus, passage-excluded bowel prepare with circulatory) and in human studies lasting several months. ${ }^{18,24-25}$

In our experiments, several plant extracts of natural origin, such as Raphanus sativus niger, ${ }^{26,27}$ Sempervivum tectorum, ${ }^{21,22}$ Cichorium intibus, ${ }^{28,29}$ Taraxacum officinale, ${ }^{30}$ Helichrysum arenarium, ${ }^{15,31,32}$ (Peroselium crispum, ${ }^{33,34}$ Anthriscus cerefolium, lyophilized extracts, Solidago canadensis ${ }^{35}$ and alcoholic and aqueous extracts of Ginkgo biloba, ${ }^{37,38}$ Hibiscus sabdariffa, ${ }^{38}$ Beta vulgaris var rubra, $13,{ }^{39,40}$ as well as silibinin, ${ }^{22,41,42}$ and silymarin compounds, ${ }^{17}$ or fruits, apples ${ }^{12}$ sour cherries ${ }^{43}$ were investigated.

Among the products, vitamin E, ${ }^{18,23-25,42,44-46}$ and Detralex ${ }^{27}$ were tested. We performed a partial phytochemical and elemental analysis of Beiqishen tea, ${ }^{10}$ Holub, Rose and Mate teas, ${ }^{18}$ as well as examined several tea with special function (Tisztító/Cleansing, Salaktalanító/ Decontaminating, Gyomortea/Stomach Tea) and green tea products were analyzed. ${ }^{47}$

These studies confirmed our hypothesis that pharmaceutical preparations are often so-called "drug bombs". In many cases, product advertising is templated and does not describe any side effects that may occur. Early we observed changes the effects of free radical reactions in the different liver diseases. In addition to fatty liver and extrahepatic cholestasis models, we also introduced the partial hepatectomy model in our research repertoire. ${ }^{2,3}$ In animal experiments, we confirmed the importance of redox homeostasis and the importance of free radical - antioxidant balance. ${ }^{13,48}$ In our research we studied the free radical changes in bile in connection with stone formation and the irritant effect of abnormal bile on the intestinal mucosa and their prevention with natural active substances. ${ }^{23,25}$ (istopathological examinations were applied to study the morphological changes. ${ }^{45,49}$

These studies have brought us closer to a better understanding of the intestinal-liver axis. ${ }^{50}$ To investigate the effect of plant-based active substances and metal ions on their free radical antioxidant status, a research repertoire was developed. During the research several drugs, lyophilisates, tea and medicines were examined. ${ }^{16,18,23,25,27,43,51-55}$

Elemental metabolism is altered in hyperlipidemia. Most toxic elements are accumulated, indicating a decrease in the liver's detoxifying capacity. Therefore, natural active substances that are capable of accelerating the depletion of these metal ions may serve 
as tools for primary prevention. Polyphenols can remove heavy metal ions from the body. ${ }^{56}$ Recent studies have confirmed that the beneficial physiological effect of Sempervivum tectorum also involves the elimination of toxic metal ions accumulated in the liver. The therapeutic use of multicomponent natural products or their enjoyment in the form of enjoyment raises several problems. I emphasize that plants can accumulate different metal ions, but it is not excluded that toxic elements are introduced into the preparations due to soil contamination. ${ }^{9,36}$ It is also unfortunate that the refreshing effect is often provided by increasing the caffeine content, so that some preparations may contain unreasonably high levels of caffeine.

This brief summary focuses on the mechanism of action of the liophylsed aqueous extract of Sempervivum tectorum in rat experiments, vacuum dried beetroot, dietary supplement containing vegetable and fruit concentrate and Raphachol bile granulate in human studies to demonstrate the broad applied methodological approach.

\section{Sempervivum tectorum}

The question was how can the polyphenol type antioxidants of Sempervivum tectorum act in hyperlipidemia and in fatty liver?

The liophylized aqueous extract of Sempervivum tectorum contains significant amounts of polyphenolic compounds resulting in superoxide anion and hydrogen peroxide/hydroxyl radical scavenger properties. This extract protects the bowel epithelial cells against damaging effects of lipids (lipid peroxides) in hyperlipidemia. The cellular immune functions changed considerably during partial hepatectomy. Sempervivum tectorum modifies cytokine production in fatty liver in partial hepatectomy. We observed that this liophylizate extract had a favorable effect on concanavalin-A-stimulated spleen cell blast transformation, lipopolysaccharide-triggered TNF- $\alpha$ production and spontaneous IL-1 activity in partial hepatectomy.

Conclusion: Sempervivum tectorum has several beneficial effects on alimentary induced fatty liver and on fatty liver after partial hepatectomy. The consumption of plant-based foods has a beneficial effect on the intestinal redox balance. ${ }^{21,44}$

\section{Vacuum dried Beta vulgaris L. ssp. esculenta var. rubra}

Beta vulgaris L. ssp. esculenta var. rubra is rich in bioactive compounds therefore it affects numerous biochemical reactions, enzyme activities and metabolic pathways, therefore this vegetable can be considered as functional food. Question: How does betaine content of Beta vulgaris L. ssp. esculenta var. rubra diminish the anemia?

Among the quaternary ammonium compounds, which have human health significance due to their biological activity, a high concentration of betaine can be found in the table beet. Betaine is an important natural molecule for treating homocystinuria, alcoholic steatosis, chemically induced liver, lung and skin cancers. This molecule helps to create choline, can help synthesis of carnitine and helps to convert homocysteine into methionine and it takes part in biologic methylation. Methylation is very important for hemoglobin synthesis. Betaine is a potential $\mathrm{HCHO}$ generator, therefore serves the $\mathrm{HCHO}$ to the methylation of globin to stabilize hemoglobin formation, considering the arginine (38), methionine (65) and the lysine (72) near the methionine (80) must be methylated and coordinated towards the central iron of heme.

\section{Folic acid plays a catalytic role in transmethylation}

In this clinical study $10 \mathrm{~g}$ natural table beet vacuum dried product was given twice daily for 1 month for 24 patients (mean age $68 \pm 8$ years) with hormone-resistant and metastatic prostate cancer treated with taxane chemotherapy, who reported their complaints themselves first, mean 3.6 \pm 2.8 years before. 18 men's data were amenable after treatment for evaluation. In addition to routine laboratory examination values of HbAlc, 9 cytokines and levels of 3 growth factors, the global parameters of redox-homeostasis, few elements, $\mathrm{Zn}$ - and free protoporphyrin levels, trans-methylation processes were determined before and one month after treatment. The measured parameters were improved during treatment. $\mathrm{Zn}$ - and free protoporphyrin levels were decreased and transmethylation ability was better as well as redox parameters, but PSA and EGF concentrations were higher more than $50 \%$ of patients in the end of the treatment.

Conclusion: Results clearly verify that iron, folic acid and betaine components as well as colorful compounds with antioxidant activity of table beet extract demand more attention as a preventive therapy in chemotherapy induced anemia. Table beet will have a great impact and application in human cancer, but because of the increasing values of EGF and PSA close medical control is necessary for patients especially during chemotherapy. ${ }^{52}$

\section{Fruit and vegetable color concentration}

In this study the question was: How can a dietary supplement act on the colectomysed patients in secondary prevention?

We studied the effect of antioxidant and metal element rich proprietary preparation "Fruit and vegetable color concentration"which contained bioactive agents - on colectomised volunteers. Components of „Fruit and vegetables color concentration” are: Sambucus nigra (berry), Vaccinum oxycoccus (extract), Morus nigra (berry), Beta vulgaris var. rubra, Vitis vinifera (berry), Hippophae rhamnoides (fruit oil, berry juice), Aronia rotundifolia (extract), Hibiscus sabdariffa (extract).

Beneficial medical effects are due to bioactive components, such as tansmethylation agent betaine, betanins, betaxanthins, vulgaxanthine, polyphenols, flavonoids, vitamins (thiamine (B1), riboflavine (B2), piridoxine (B6), ascorbic acid, biotin and folic acid) as well as soluble fiber, pectin and different metal elements (e.g. Al, B, Ba, $\mathrm{Ca}, \mathrm{Cu}, \mathrm{Fe}, \mathrm{K}, \mathrm{Mg}, \mathrm{Mn}, \mathrm{Na}, \mathrm{Zn}$ ), which act on various physiological routes. According to newer researches, these colored pigments have antioxidant activity and play an important role in the development of antioxidant status in the human organism.

This concentration ( $2 \times 3 \mathrm{~g} /$ day) was added to 28 adult patients as secondary prevention after 5-10years of their colectomy and 9 healthy volunteers for 3 months. Several routine laboratory parameters were not altered after treatment compared to start time data in colectomysed patients and control volunteers. The treatment did not change the tumor marker levels significantly, but in each case the values were elevated in examined groups. Redox parameters of colectomysed patients showed strengthened free radical reactions, namely rebound effect against antioxidant excess, although tendency was observed in controls as well. Anti-inflammatory effects of the natural product were not clearly observed.

The dietary supplement treatment negative influenced the plasma and erythrocyte free radical levels and the HbAlc concentration, 
diminished the reducing power similarly reduced the GSHPx- level in the asymptomatic patients. The HbAlc levels well correlated with free radical levels of erythrocytes and the lowered antioxidants status.

Tumor marker AFP, CEA and CA-19-9 levels of operated patients were higher in most cases, and only in few cases the normal values exceeded comparison with baseline ones. ${ }^{57-59}$

Conclusion: Moderate nutritional customs with natural scavengers or antioxidants can help to restore the normal function of tissues and organs, but the immoderate consumption of vitamins and other bioactive agents, such as polyphenols, flavonoids, isothiocyanates etc. are contraindicated.

\section{Raphachol}

Hypothesis: The anti-inflammatory, lipid peroxidation lowering and radical scavenging properties as well as gallstone dissolving effect of black radish root may be beneficial in reducing of bowel discomfort of patients with IBD. The active ingredients of the preparation can significantly influence the redox state of intestinal epithelial cells. The mild bactericidal, fungicidal action can protect the normal intestinal flora of the intestine. The question was, while what time does the beneficial effect of treatment occur and does the unwanted side effect occur during several months of treatment?

\section{Patients were under regular medical control and received adequate treatment of IBD}

Blood samples were collected before the first administration of Raphacol (0.2 g/day), and after 3, 6, 9 and 12 months of treatment.

No significant differences were observed in serum parameters during the 12 months of Raphacol treatment in the moderately severe condition of IBD during the term. At the end of the treatment, IL-6 level was decreased, which was also measurable at the end of 3 months after treatment, and free SH-group concentrations increased. Redoxparameters were deteriorated in the plasma. Undesirable changes of sera bile acid were detected by the end of the period.

Raphachol significantly reduced erythrocyte chemiluminescence and moderately reduced erythrocyte $\mathrm{HbA1c}$ levels by month 9 , which was favorable. From the data obtained, it can be concluded that the Raphacol granule composition can exert a long-term influence on the redox homeostasis even at $0.2 \mathrm{~g}$ /day concentration. It probably modifies redox reactions at several levels and at several points. New redox homeostasis was formed.

Conclusion: Continued use of Raphachol is not recommended. ${ }^{48,60-63}$

\section{Discussion}

The presented studies are very important for the safe therapeutic uses of natural products. In Hungarian universities in this field the examinations are continued in several diseases, especially in tumors with drug extracts and isolated bioactive agents, considering the several failure of targeted cancer therapy. T\&CM, used worldwide and integrated into EBHC, can play an important part in health services, supporting health, and addressing chronic NCDs. Its focus is on patient-centered care, and it is linked to the cultural background and needs and values of patients. Transparency and information are provided by a strong and di $\square$ erentiated evidence base regarding benefit and implementation of T\&CM approaches, assessing e $\square$ cacy, e $\square$ ectiveness, safety, costs, modes of action, patient and public perspective, ethical issues, educational matters, professionalism, and healthcare procedures and concepts. A broad research strategy, as outlined for Traditional Medicine, supports research and healthcare, transcultural understanding, and collaboration among di $\square$ erent stakeholders of healthcare. ${ }^{64-67}$

\section{Acknowledgments}

None.

\section{Conflicts of interest}

There is no conflict of any interest.

\section{Funding}

None.

\section{References}

1. György I, Blázovics A, Fehér J, et al. Reactions of inorganic free radicals with liver protecting drugs. Radiat Phys Chem. 1990;36:165-167.

2. György I, Antus S, Blázovics A, et al. Substituent effects in the free radical reactions of silybin radiation-induced oxidation of the flavonoid at neutral pH. Int J Radiat Biol. 1992, 61(5):603-609.

3. Blázovics A, Fehér E, Fehér J. Role of free radical reactions in experimental hyperlipidemia in the pathomechanism of fatty liver. In: G. Csomós, J. Fehér editors. Free Radicals and Liver. Berlin: SpingerVerlag. 1992; p. 96-123

4. Blázovics A, Fehér E, Kéry Á, et al. Liver protecting and lipid lowering effects of Sempervivum tectorum in the rats. Phytother Res. 1993;7:98100 .

5. Blázovics A, Lugasi A, Kemény T, et al. Membrane stabilizing effects of natural polyphenols and flavonoids from Sempervivum tectorum on hepatic microsomal mixed-function oxidase system in hyperlipidemic rats. J Ethnopharm. 2000;73(3):479-485.

6. Blázovics A, Lugasi A, Szentmihályi K, et al. Reducing power of the natural polyphenols of Sempervivum tectorum in vitro and in vivo. Acta Biol Szegediensis. 2003;47(1-4):99-102.

7. Lugasi A, Dworschák E, Blázovics A, et al. Antioxidant and free radical scavenging properties of squeezed juice from black radish (Raphanus sativus L. Var, niger) root. Phytotherapy Res. 1998;12(7):502-506.

8. Szentmihályi K, Blázovics A, Lugasi A, et al. Effect of natural polyphenol-type antioxidants (Sempervivum tectorum and Raphanus sativus L. var. niger extracts) on metal ion concentrations in rat bile fluid. Curr Top Biophys. 2000;24(2):203-207.

9. Szentmihályi K, Fehér E, Vinkler P, et al. Metabolic alterations of toxic and none essential elements by the treatment of Sempervivum tectorum extract in hyperlipidemic rat model. Toxicol Pathol. 2004;32(1):50-57.

10. Héthelyi É, Szabó L, Rapavi E, et al. Evidence-based medicine in phytotherapy, Oil, Soap, Cosmetics. 2001;50(2):67-75.

11. Héthelyi É, Szarka Sz, Antal I, et al. Phytochemical and biochemical examination of Gentiana lutea L., Oil, Soap, Cosmetics. AGRIS. 2004;53(5):204-211.

12. Balázs A, Tóth $\mathrm{M}$, Blazics B, et al. Investigation of dietary important components in selected red fleshed apples by GC-MS and LC-MS. Fitoterapia. 2012;83(8):1356-1363.

13. Blázovics A, Sárdi É. Methodological repertoire development to study the effect of dietary supplementation in cancer therapy. Microchem J. 2018;136:121-127. 
14. Blázovics A, Prónai L, Kéry Á, et al. Natural antioxidant extract from Sempervivum tectorum. Phytother Res. 1993;7(1):95-97.

15. Czinner E, Lemberkovics É, Kéry Á, et al. Biologically active components of Helichrysum arenarium L. Eur J Drug Metab Pharmacokinetics. 1999;24(4):309-313.

16. Lugasi A. The effect of food-derived antioxidants in primary and secondary prevention: Animal and human studies. Ph.D. Theses, Budapest; 2001.

17. Hagymási K, Blázovics A, Lengyel G, et al. Oxidative damage in alcoholic liver disease. Eur J Gastroent Hepatol. 2001;13(1):49-53.

18. Kocsis I, Szentmihályi K, Rapavi E, et al. Effect of Cichorium intibus (L.) on the redox balance and metal ion content of fatty liver in hyperlipidemic rats. Trace Elements and Electrolytes. 2004;21(4):262268.

19. Blázovics A, Fehér E, Fehér J. Role of free radical reactions in experimental hyperlipidemia in the pathomechanism of fatty liver. In: G. Csomós, J. Fehér editors. Free Radicals and Liver. Berlin: SpingerVerlag. 1992; p. 96-123.

20. Blázovics A, Fehér E, Kéry Á, et al. Liver protecting and lipid lowering effects of Sempervivum tectorum in the rats. Phytother Res. 1993;7:98100 .

21. Blázovics A, González-Cabello R, Barta I, et al. Effect of liverprotecting Sempervivum tectorum extract on the immune reactivity of spleen cells in hyperlipidemic rats. Phytother Res. 1994;8(1):33-37.

22. Blázovics A, Horváth ÉM, Barta I, et al. Sempervivum tectorum and liver regeneration. In: Proc. of the Oxygen free radicals and scavengers in the natural sciences. Budapest: Akadémiai Kiadó. 1993:293-300.

23. Horváth ÉM, Gonzalez-Cabello R, Blázovics A, et al. Effect of silibinin and vitamin $\mathrm{E}$ on restoration of cellular immune response after partial hepatectomy. J Ethnopharmacol. 2001;77(2-3):227-232.

24. Lugasi A, Blázovics A, Lebovics VK, et al. Beneficial health effect of black radish and in vivo experimental conditions. Phytochemistry and Pharmacology. 2001;2:365-375.

25. Sipos P, Hagymási K, Lugasi A, et al. Effect of black radish root (Raphanus sativus L. var niger) on the colon mucosa in rats fed a fat rich diet. Phytother Res. 2002;16(7):677-679.

26. Lugasi A, Dworschák E, Blázovics A, et al. Antioxidant and free radical scavenging properties of squeezed juice from black radish (Raphanus sativus L. Var, niger) root. Phytotherapy Res. 1998;12(7):502-506.

27. Rapavi E, Szentmihályi K, Kocsis I, et al. The effect of hesperidin and diosmin onion concentration and antioxidant defense system in fatty liver in rats. Metal elements in environment, medicine and biology. 5th International Symposium, Timisoara, Romania. 2002.

28. Kocsis I. Hagymási K, Kéry Á, et al. Effect of chicory on pancreas status of rats in experimental hyperlipidemia. Acta Biol Szegediensis. 2003;47(1-4):143-146.

29. http://semmelweis.hu/wp-content/phd/phd_live/vedes/export/ valilaszlo.d.pdf

30. Hagymási K, Blázovics A, Lugasi A, et al. In vitro antioxidant evaluation of dandelion (Taraxacum officinale Web.) water extract. Acta Aliment Hung. 2000;5(1):1-7.

31. Czinner E, Hagymási K, Blázovics A, et al. In vitro antioxidant properties of Helichrysum arenarium L Moench. J Ethnopharmacol. 2000;73(3):437-443.

32. Czinner E, Hagymási K, Blázovics A, et al. The in vitro effect of Helichrysi flos on microsomal lipid peroxidation. J Ethnopharmacol. 2001;77(1):31-35.
33. Fejes Sz, Blázovics A, Lemberkovics É, et al. Free radical scavenging and membrane protective effects of methanol extracts from Anthriscus cerefolium and Petroselinum crispum (Mill.) Nym ex AW Hill. Phytother Res. 2000a;14(5):362-364.

34. Fejes Sz, Blázovics A, Lugasi A, et al. In vitro antioxidant activity of Anthriscus cerefolium L (Hoffm). J Ethnopharmacol. 2000b;69(3):259265 .

35. Apáti P, Balázs A, Blázovics A, et al. Use of in vitro methods to investigate the inhibitory effect of Solidago canadensis L. on lipid peroxidation. Current issues in free radical research. Budapest: MSZKT Workshop; 2004.

36. Stefanovits-Bányai É, Bertényi-Divinyi Zs, Kiss AS, et al. Comparison of calcium, magnesium, potassium and sodium contents of Ginkgo biloba L. leaves from Hungary. J Elementol. 2002a;7(1):49-56.

37. Szentmihályi K, Blázovics A, Lugasi A, et al. Effect of natural polyphenol-type antioxidants (Sempervivum tectorum and Raphanus sativus L. var. niger extracts) on metal ion concentrations in rat bile fluid. Curr Top Biophys. 2000b;24(2):203-207.

38. Rapavi E, González-Cabello R, Szentmihályi K, et al. The effect of calyx infusion of Hibiscus sabdariffa L. on T-cells-mediated immune response in mitogen-induced blastogenesis of human lymphocytes in vitro. Acta Alim Hung. 2006;35(3):281-288.

39. Váli L, Fébel H, Stefanovits-Bányai É, et al. Duodenum protecting effects of table beet (Beta vulgaris var. rubra) during hepatic ischaemiareperfusion. Acta Alimentaria. 2006;35(9):445-453.

40. Váli L, Stefanovits-Bányai E, Szentmihályi K, et al. Liver protecting effects of table beet (Beta vulgaris var. rubra) during ischemiareperfusion. Nutrition. 2007;23(2):172-178.

41. Blázovics A, Somogyi A, Nagy É, et al. Silibinin kezelés hatása a máj drog-metabolizáló enzimrendszerére kísérletes hyperlipidaemiában. Kisérletes Orvostudomány. 1988;151-158.

42. Fehér J, Blázovics A, Gonzalez-Cabello R, et al. Effects of silibinin and vitamin $\mathrm{E}$ on lipid peroxidation and cellular immunoreactivity in experimentally induced fatty liver of rats. Med Sci Monit. 1996;2(4):397403.

43. Papp N, Blázovics A, Fébel H, et al. Antihyperlipidemic effects of sour cherries characterized by different in vitro antioxidant power and polyphenolic composition. Plant Foods Human Nutr. 2015;70(4):408413.

44. Gonzalez-Cabello R, Blázovics A, Horváth ÉM, et al. Effect of vitamin $\mathrm{E}$ on the immuno reactivity of spleen cells in hyperlipidemic rats. Acta Med Hung. 1993;49(1-2):101-108.

45. Ágoston M, Örsi F, Fehér E, et al. Sylimarin and vitamin E reduce amiodarone-induced lysosomal phospholipidosis in rats. Toxicology. 2003;190(3):231-241.

46. Hagymási K. A máj redox-homeosztázisának tanulmányozása kísérletes és humán vizsgálatokban: antioxidáns kezelés - antioxidáns betegség. PhD-tézisek. Budapest, 2002.

47. Rapavi E, Stefanovits-Bányai É, Szentmihályi K, et al. Trace elements and antioxidant properties of Hungarian dried herbs. New results in the trace element research. $1^{\text {st }}$ edn. Pais, Budapest: Szent István University; 2003. p. 210-220.

48. Blázovics A, Kovács Á, Lugasi A. The effect of long term antioxidant treatments on redox homeostasis in clinical studies. Hungarian Med J. 2007;1:83-95.

49. Blázovics A, Kéry Á, Fehér E, et al. Natural antioxidants in liver therapy. Current Topics of Biophysics. 1997;20:14-30, 
50. Egresi A, Kovács Á, Szilvás Á, et al. Bél-máj tengely vizsgálata colitis ulcerosaban-retrospektív tanulmány. Orvosi Hetilap. 2017;158(26):1014-1021.

51. Blázovics A, Lugasi A, Hagymási K, et al. Natural antioxidants and tissue regeneration. In: Curative effect and reaction mechanism. Phytochem Pharmacol. Texas, USA: Sci Tech Publishing LLC. 2002; Vol 8(2):93-134.

52. Blázovics A, Nyirády P, Romics L, et al. How can cancer-associated anemia be moderated with nutritional factors and how do Beta vulgaris L. ssp. esculenta var. rubra modify the transmethylation reaction in erythrocytes in cancerous patients? In: DS Silverberg, editor. Anemia Intech. 2012;1-23.

53. Kocsis I, Lugasi A, Hagymási K, et al. Beneficial properties of black radish root (Raphanus sativus L. var. niger) squeezed juice in hyperlipidemic rats, biochemical and chemiluminescence measurements. Acta Alim Hung. 2002;32(1):185-190.

54. Szentmihályi K, Fehér E, Vinkler P, et al. Metabolic alterations of toxic and none essential elements by the treatment of Sempervivum tectorum extract in hyperlipidemic rat model. Toxicol Pathol. 2004;32(1):50-57.

55. Szentmihályi K, Ladó K, Rapavi E, et al. Investigation and evaluation of mineral content of medicinal plants in the context of complex prevention research. Széchenyi Symposium. 1/016. NKFP 2004a

56. Blázovics A, Szentmihályi $\mathrm{K}$, Lugasi A, et al. In vitro analysis of the properties of Beiqishen tea. Nutrition. 2003;19(10):869-875.

57. Szilvás A, Blázovics A, Székely G, et al. Comparative study between the free radicals and tumor markers in patients with gastrointestinal tumors. J Physiology Paris. 2001;95(1-6);247-252.

58. Szilvás A1, Sźékely G, Tarján $Z$, et al. Three-dimensiona ultrasosography, virtual colonoscopy and endorectal magnetic resonance imaging in the diagnosis of complicated inflammatory bowel disease. Endoscopy. 2002;34(1):94.

59. Blázovics A, Kursinszki L, Papp N, et al. Is professional prescription of a commercially derived dietary supplement in colectomysed patients necessary? Eur J Integr Med. 2016;8:219-226.

60. Blázovics A, Lugasi A, Kemény T, et al. Membrane stabilizing effects of natural polyphenols and flavonoids from Sempervivum tectorum on hepatic microsomal mixed-function oxidase system in hyperlipidemic rats. J Ethnopharm. 2000;73(3):479-485.
61. Blázovics A, Lugasi A, Szentmihályi K, et al. Reducing power of the natural polyphenols of Sempervivum tectorum in vitro and in vivo. Acta Biol Szegediensis. 2003;47(1-4):99-102.

62. Blázovics A, Kovács Á, Lugasi A. The effect of short and long term antioxidant treatments on redox homeostasis in experimental and clinical studies. In: V Watkins Sarah, editor. Nova Science Publisher. 2015:1-34.

63. Blázovics A, Rapavi E, Hagymási K, et al. Is Medical control of herbal tea consumption necessary? ISHS Acta Horticulture No. 629. 2004:153160 .

64. Fejes Sz, Blázovics A, Lugasi A, et al. Free radical scavenging and membrane protecting effect of methanol extracted fraction of Parsley. Hungary: Acta Aliment. 2000;29(1):81-87.

65. Fejes Sz, Kéry Á, Blázovics A, et al. Petroselium crispum (Mill.) Nym ex AW Hill in vitro antioxidáns hatásának vizsgálata. Hungary: Acta Pharmaceut. 1998;68(3):150-156.

66. Fehér E, Blázovics A, Horváth ÉM, et al. Effect of Sempervivum tectorum extract in the experimental hyperlipidemia and alcoholism. A histological study in the liver and jejunum. In: J Fehér, A Blázovics, B Matkovics M, et al, editors. Role of Free Radicals in Biological Systems. Budapest, Hungary: 1993; p. 45-57.

67. Hagymási K, Kocsis I, Lugasi A, et al. Extrahepatic biliary obstruction: can sylimarin protect liver function? Phytother Res. 2002, 16(1):1-3.

68. Prònai $\mathrm{L}$, Blåzovics $\mathrm{A}$, Horvåth $\mathrm{M}$, et al. Superoxide activity of dihydroquinoline type derivative ( $\mathrm{CH} 402$ and MTDQ-DA). Free Rad Res Comms. 1993;19(5):287-296.

69. Sípos P. Free radical changes of bile in gallstone diseases and their effect on intestinal mucosa. Ph.D. Theses. 2001.

70. Mohanta TK, Tamboli Y, Zubaidha PK. Phytochemical and element analysis of Ginkgo biloba L. from Hungary. Nat Prod Res. 2014;28(10):746-752. 